Article

\title{
Exploring Determinants of Innovation Capability in Manufacturing Companies Operating in Poland
}

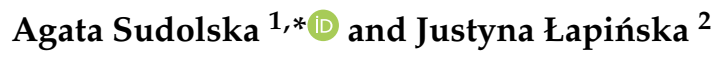 \\ 1 Department of Enterprise Management, Faculty of Economic Sciences and Management, \\ Nicolaus Copernicus University, 87-100 Torun, Poland \\ 2 Department of Organizational Behaviour and Marketing, Faculty of Economic Sciences and Management, \\ Nicolaus Copernicus University, 87-100 Torun, Poland; justlap@umk.pl \\ * Correspondence: aga@econ.umk.pl
}

Received: 7 August 2020; Accepted: 28 August 2020; Published: 31 August 2020

\begin{abstract}
The innovation capability of a company is considered the determinant of its competitiveness in the long-term. Therefore, it is of increasing importance to understand the critical variable behind a firm's innovation capability. The paper explores these issues and contributes to the research on the factors that drive a company's innovation capability. The aim of the paper is to identify which factors determine the innovation capability of manufacturing enterprises operating in Poland. In the theoretical part, it provides an overview of recent contributions to the literature on a company's innovation capability enhancers. The empirical contribution of the paper refers to recognising the relationship between the certain practices pursued by Polish manufacturing enterprises and their innovation capability measured by innovation output. Using a model for panel data, the study finds that that the factors driving innovation capability of manufacturing enterprises operating in Poland are the following: inter-organisational cooperation, hiring employees in research and development (R\&D) activities as well as firms' internal expenditures on R\&D. The study is based on the data from publications of the Central Statistical Office of Poland, which contain information on the activities of manufacturing enterprises and reports presenting the results of research on the innovation capability of enterprises.
\end{abstract}

Keywords: innovation capability; innovation drivers; panel data

\section{Introduction}

In today's highly complex and rapidly changing economic reality, a firm's ability to innovate has become an imperative for survival and success. It results from the fact that globalisation calls for new ways to compete and meet the demand for increasingly innovative services and products offered on the market [1-3]. Currently, enhancing the ability to innovate is considered to be a prerequisite for a company to achieve a high level of competitiveness and sustainability. There is a considerable agreement among the researchers and practitioners on the view that innovation is closely related not only to a firm's sustainability but also to the sustainability of the whole business environment [4]. The ability to innovate is also said to be an attribute of the companies that aim to improve their competitive advantage while supporting sustainability in the long term $[5,6]$. In the relevant literature, company competitiveness is discussed from several perspectives, however generally the ability to generate several types of innovations is perceived as a very significant source of a firm's competitive advantage as well as a firm's sustainability $[7,8]$. It is said that business entities that aspire to remain competitive in today's economy for a long time need to treat the development of their ability to innovate as a philosophy of continuous improvement towards sustainability [8]. Furthermore, contemporary companies aimed at sustainability have to enhance their ability to meet and satisfy the stakeholder 
demands without compromising their ability to meet the needs of future stakeholders [9]. This, in turn, requires being able to innovate. Interesting research regarding this issue is provided by Saadi and Che Razak and Sriboonlue et al. [7,8]. Saadi and Che Razak propose a conceptual framework to analyse the relationship between a firm's technological innovation capability that enables innovation and its organisational sustainability, focusing on the mediating role of innovative human capital. The authors argue that technological innovation capability is a significant source of a company's competitive advantage and sustainability in the long term [7]. Whereas, Sriboonlue et al. investigated the auto parts industry in Thailand and they empirically proved the existence of a significant positive relationship between innovation capability (simply meaning the ability to innovate) of a firm and firm's performance in terms of innovation. Sriboonlue et al. highlight the significance of innovation capability as one of the crucial tools to achieve a firm's sustainability in a rapidly changing environment [8]. Business entities today are aware of the need to create the blended value of reducing the environmental impact as a result of their operations and activities $[10,11]$ as well as considering their impact on society in terms of securing the well-being of future generations $[12,13]$. Incorporating sustainability into the enterprise's activities aimed at innovation may happen both on the organisational level and the inter-organisation level. Contemporary companies, while working on innovations, frequently cooperate with other business entities, research institutions, universities, etc. and this enables them to build a community of practice around sustainability [14,15]. As sustainability has recently become an issue of global competitiveness, companies are forced to implement innovative thinking in the area of corporate strategy, investment prioritisation, technology development, etc. [16]. Given the above, modern companies consider an increase in efficiency in the sphere of their innovation capability a priority. The term "innovation capability" has aroused the attention and interest of multiple researchers and has been used in the innovation literature for decades [17-22]. Despite this, there is still a discussion about its meaning [23]. According to Lawson and Samson, a firm's innovation capability is the ability to continuously transform knowledge and ideas into new products, processes and systems for the benefit of the company and its stakeholders [24-26]. In the same vein, Neely et al. as well as Esterhuizen et al. claim that an enterprise's innovation capability refers to its potential to innovate [17,27]. Olsson et al. enriched the innovation capability definition by adding the statement that it is the ability of the firm to continuously generate innovations as a response to its dynamic environment [18]. Additionally, Wonglimpiyarat, while discussing innovation capability nature, focuses on a firm's ability to make major modifications to improve existing technologies or create completely new ones [28]. Summing up the definitions mentioned above, innovation capability may be understood as an enterprise's ability to successfully innovate by developing new products, processes as well as achieve superior technological and/or management performance [29]. Developing a firm's innovation capability may include such activities as internal research and development, external research and development, provision of modern machinery, equipment, computer hardware and software to produce new or significantly improved products and processes, obtaining the opinions of external experts, training for innovation, activities leading to innovation in the market and other activities such as software testing, software development, etc. [30,31].

While discussing the above-said issues, the question of the determinants of a firm's innovation capability arises among the most important management practices. It is particularly crucial for Polish enterprises due to the fact that most countries within the EU are ranked higher than Poland in regard to firms' ability to innovate. Based on the relevant literature, there are multiple aspects affecting a company's innovation capability. Generally, they may be categorised as the issues referring to a firm's resources, interaction with the environment, internal processes and organisational attributes [21,32]. As far as the aspects of the resources and a firm's interaction with its environment are concerned, a growing number of authors highlight the significance of inter-organisational cooperation [33-40]. This results from the fact that in today's environment, inter-organisational cooperation, understood as a mutually beneficial and well-defined relationship entered by two or more organisations to achieve common goals [41], provides essential building blocks to access dispersed capabilities. As such, it has 
far-reaching implications for innovating. Regarding a company's internal processes, several authors point to such aspects as organisational strategy focused on innovation, the development of human capital of the firm as well as R\&D expenditures [24,42-46]. Within the aspects regarding organisational attributes stimulating a firm's innovation capability, most authors indicate leadership, risk acceptance, organisational culture conducive to innovation and efficient communication enabling knowledge sharing and learning [24,42,47]. Finally, several pieces of research claim that public support aimed at the development of a firm's R\&D sphere is an essential enhancer of its innovation capability $[44,48,49]$.

Research on a firm's ability to innovate is generally fragmented. Several authors focus on particular areas such as inter-firm cooperation, the human capital of the company, knowledge management, creating organisational culture and a climate favourable to innovation, etc. [43,50-58]. However, there is a lack of research, including all issues above while analysing how to improve an enterprise's ability to innovate. Thus, we perceive this paper as an attempt to fill this research gap using the example of manufacturing companies operating in Poland. In order to find out the factors determining the innovation capability of manufacturing enterprises operating in Poland, an econometric model for panel data was constructed. The source of data for the analyses carried out were publications of the Polish Central Statistical Office, which contain basic information on the activities pursued by manufacturing enterprises and reports presenting the results of research on the innovation-oriented activities of enterprises. Such research is conducted in European Union countries as part of the international Community Innovation Survey (CIS) research program.

The paper contributes to the knowledge and research on the factors that drive a company's innovation capability that is fundamental for business competitiveness. The aim of the paper is the attempt to identify which factors determine the innovation capability of manufacturing enterprises operating in Poland. In the theoretical part, the paper provides an overview of recent contributions to the literature on a company's innovation capability enhancers. The empirical contribution of the study refers to recognising the relationship between the certain practices pursued by Polish manufacturing enterprises and their innovation capability measured by innovation output. Our paper provides important managerial implications. It highlights that better recognition of the factors driving a firm's innovation capability can help managers find the best ways to increase the efficiency of investments in enhancing a firm's ability to innovate.

\section{The Main Drivers for a Firm's Innovation Capability}

As highlighted by the resource-based view of the firm, all organisations differ in their resources and capabilities in important and durable ways that affect their competitive advantages [59-62]. Over the past decades, it has been recognised that under the conditions of strong competition several business entities are not able to stay self-sufficient in the field of creating their resource bases, in particular with regard to knowledge assets. The changes in the environment force contemporary companies to focus on modifying their resources. If they want to retain their competitiveness in the hypercompetitive landscape, they need to monitor and modify their resources permanently and fill in the niches in their resource bases. However, as accessing the resources needed for innovation is often difficult for individual companies, they start searching for the desired resources outside. Under such conditions, inter-organisational cooperation has been recognised as a good way of improving a firm's conduct in the field of innovation capability. Inter-organisational cooperation is defined as a mutually beneficial and well-defined relationship between two or more organisations created in order to achieve their common goals [41]. There is no doubt that in the contemporary economy, enterprises acting alone are not best placed to capture the opportunities available in the market or cope with the challenges that face them. Inter-organisational cooperation allows companies to gain access to global markets, absorb new technologies, share knowledge, human and material resources [34,37,63]. As emphasized by Miotti and Sachwald, currently the research needed to innovate becomes increasingly complex and multi-disciplinary. This forces business entities to seek resources outside their boundaries and thus create several inter-organisational relationships [63]. 
Obtaining the benefits of inter-organisational cooperation has been explained by several theories in the field of management, among which the most common concepts are the above mentioned resource-based view of the firm [59,60], transaction cost theory $[64,65]$ or organisational learning theory [66]. According to the resource-based view of the firm, enterprises that are not self-sufficient in creating their own resource base, need specific resources from their environment, thus becoming dependent on it. This implies the fact that enterprises are forced to use external sources of resources by establishing various links with other organisations [36,37,67-69]. As highlighted by several researchers, the benefits from inter-firm cooperation are obtained through access to complementary assets or through accessing particular resources in a more cost-effective way [50,51,63,70-72]. Access to complementary assets from outside the company is particularly important for R\&D activities pursued by firms. Business entities conducting complex, expensive and thus risky research for innovation frequently search for R\&D cooperation [63]. The benefits resulting from co-operators' resources complementarity are particularly significant, while none of the complementary resources owned by the cooperating enterprises alone contribute to building a competitive advantage, when combined with the resources of a second enterprise their value increases many times as it brings the integration of resource capabilities that allow innovation [73,74]. Much research presented in the literature of the field proves that inter-organisational cooperation has a positive impact on a firm's innovation performance [63,70,72-75].

Inter-organisational cooperation has also been recognised as spreading the risks of innovating. Inter-organisational cooperation can reduce these risks for individual participants by sharing the costs involved, reducing the time span of innovation and increasing the possibility of success [74]. Due to the fact that expenses involved in innovating can be high, sharing the costs of innovating can contribute to reducing these risks as well as enabling organisations to simultaneously pursue multiple innovation projects [76]. Furthermore, the decrease in the level of co-operators' costs is related to the phenomenon of economies of scale and economies of scope. The issue of economies of scale is clearly highlighted in the literature on building inter-organisational relations [77-79]. Pooling co-operators' resources enables them to reach a scale of production that they could not reach by themselves. The economies of scale arise not only in the area of production but also in the field of R\&D. This may result in co-operators' ability to innovate $[35,80]$. Achieving scope benefits within inter-organisational cooperation refers to the fact that cooperating organisations provide the opportunity to increase their potential without the need to create additional market capacity. The access to new competencies obtained from partners with whom the company cooperates improves the competitiveness of the newly created organisational system, provided that the costs of transferring these competencies are lower than the costs of developing such skills on their own or the costs of acquiring them on the intermediate market [81,82]. Furthermore, inter-organisational cooperation has been recognised as contributing to knowledge transfer, stimulating the generation of new ideas and contributing to interactive learning $[36,83,84]$. This directly refers to enhancing a company's ability to innovate, both by generating knowledge inside a firm and acquiring new knowledge from outside [36]. These issues are discussed within a firm's absorptive capacity research stream [10,11,43,52,85-87]. The concept of absorptive capacity was first proposed by Cohen and Levinthal who use this term to label a firm's ability to innovate and thus be dynamic. The aforesaid authors define absorptive capacity as the ability of a firm to recognise the value of new, external information, assimilate it and apply it to commercial ends [52]. While considering inter-organisational cooperation and its benefits in terms of innovation, it should be noted that there is increasing evidence in the academic literature that merely entering into inter-organisational cooperation does not increase innovation definitely $[10,88]$. Taking the perspective of the knowledge-based view, innovation is closely related to organisational learning [89]. Thus, in the contemporary economy, companies that aim at innovation are forced to engage in interactive learning to create know-how collectively [90]. It results from the fact that by enlarging an enterprise' s knowledge base and accessing the knowledge that can augment its sources of expertise, interactive learning may help to strengthen its innovativeness and market position [91,92]. Moreover, a firm's absorptive capacity allows better assessment of the 
benefits derived from new technologies with regard to their ability to reduce potential liability costs, legal fees, or product take-back costs, or to leverage production efficiencies and waste reduction [93].

The idea of absorptive capacity is closely related to the firm's human capital. In the relevant literature, absorptive capacity is described as the collective ability of a firm resulting from the individual abilities of its members whose prior knowledge and experience provide the ability to recognise new information, assimilate it and create value out of it [52,94]. This directly refers to human capital significance in knowledge creation and innovation. Multiple researchers highlight the issue of human capital in enhancing a firm's ability to innovate [43,53-55,95]. At present, there is considerable agreement among researchers and practitioners on the view that a firm's ability to innovate depends, to a great extent, on intangible assets and knowledge that are at its disposal and on the manner in which it is able to employ these [96]. As mutual learning occurs between the company and its individuals, the company accumulates such knowledge over time and learns from its employees in order to generate innovations $[43,97]$. It has been empirically proven that employees' competencies, knowledge, creativity, capacity to resolve problems, entrepreneurial spirit, disposition or aptitudes for life-long learning, etc., appear to be critical elements for the company's ability to develop and generate innovations $[54,95]$. Several previous pieces of research have proved the critical role of absorptive capacity in enhancing a company's innovation capability [11,66,84,98-100]. Presently, innovation increasingly requires multidisciplinary knowledge, in particular in the markets dominated by knowledge intensity and specialisation [74]. Furthermore, an enterprise's innovativeness depends not only on transferring knowledge but also on its ability to integrate different kinds of knowledge and to coordinate the knowledge flow among different organisations in the market $[74,91,100]$.

Companies may practise inter-organisational cooperation through close relationships with customers, suppliers, universities, research institutions or other public research centres [35,101-105]. Furthermore, an enterprise may participate in alliances with its competitors, aimed at technology transfer or joint product development [69,106-108]. A firm can also participate in clusters that allow companies to speed up the dissemination of the network relationships in general regional economic space. In addition, a variety of different sources of technological knowledge and relationships facilitates the combination of factors in achieving competitive advantage and becomes a prerequisite for innovation generated by cluster participants [109]. Functioning in a cluster increases a firm's opportunities for obtaining new and attractive resources and sales markets, as well as subcontractors [110,111]. Taking the perspective of clusters, several researchers claim that cooperation with research institutions brings tangible benefits to enterprises that undertake it $[112,113]$. Through intensive cooperation between companies and research institutions within clusters, the knowledge transfer is accelerated, allowing enterprises to benefit from the research findings so that they can market innovative products and services each more expediently and competitively. It also helps research institutions to effectively find partners in the industry to realise their research projects. Cluster initiatives and networks are thus able to increase the innovation capability of enterprises significantly and to contribute to the profiling and positioning of the regions in global competition [114]. Several pieces of research prove that enterprise participation in clusters brings about the benefits related to major technological evolutions among cluster members leading to developing new processes and products [114-117].

Hypothesis 1 (H1). There is a positive relationship between the innovation capability of manufacturing enterprises operating in Poland and their inter-organisational cooperation.

Hypothesis 2 (H2). Inter-organisational cooperation of manufacturing enterprises in the form of cluster initiatives is a factor stimulating their innovation capability.

The primary source of knowledge that constitutes the company's absorptive capacity is R\&D. This is due to the fact that $R \& D$ generates innovation and creates knowledge, which allows enterprises to develop the capability to manage data and information from many sources [43]. Multiple researchers agree that $R \& D$ investments have a positive effect on a firm's innovation capability $[44,48,49,63,118-121]$. 
Cohen and Levinthal argue that apart from the fact that R\&D obviously generates innovation, it also develops the firm's ability to identify, assimilate and exploit knowledge from the environment which is recognised as a firm's absorptive capacity [85]. As R\&D is said to be one of the drivers of innovation, $\mathrm{R} \& \mathrm{D}$ expenditure is one of the key indicators used to monitor resources devoted to science and technology worldwide [122]. It has also been proven that to maximise the benefits of a firm's R\&D expenditures, the level of R\&D spending should match up with a company's aims and strategy [123]. Very interesting results are provided by Ortega-Argilés et al. who have investigated European manufacturing and service companies taking the period 1990-2008. The aforementioned authors confirmed that a firm's R\&D expenditures have a positive impact on its performance, particularly from an innovation perspective [124]. Also, Gkypali et al. came up with engrossing results regarding the impact of a firm's internal innovation efforts on its innovation performance. The aforesaid authors claim that internal R\&D activities pursued by Greek companies have a positive effect on their innovation output. Interestingly, they discovered that the diversity in external firm collaborations has a negative impact on a company's innovation output, elevating the significance of the optimal balance that is needed between a firm's internal investments in $R \& D$ and the diversity of its R\&D collaborations [70].

However, the approach to innovation as a sole result of R\&D investments is being criticised in the relevant literature [44]. Such simplified reasoning leads to the incorrect qualification of companies as innovative or not. Several researchers claim that companies belonging to low technological industries such as food, rubber, metalworking, etc. present a high level of R\&D investment, while companies classified as highly technological due to their sector, for example, pharmaceutical firms in India or the electronics industry in China, invest very little or nothing in R\&D. It results from the fact that much of the technology applied by these companies comes from headquarters abroad [44,125-127]. As a result, enterprises with low levels of investment in $R \& D$ end up being understood as non-innovators, which is not necessarily true.

Another significant issue related to a company's R\&D expenditures and effort in terms of a firm's innovation capability regards the interaction between R\&D and human capital within the company [128]. D' Amore et al., argue that other than a positive and significant relationship between human capital embodied in a firm's workforce and its ability to generate innovation, there is also a complementarity between human capital of the company and its R\&D efforts. The aforementioned authors claim that the higher the company's expenditures in $R \& D$, the stronger the relationship between human capital and the firm's ability to innovate [129]. The conducted efforts and expenditures of R\&D should be aligned with the company's strategy which is said to be an important enhancer of the firm's innovation capability $[24,42,130,131]$. A company's strategy determines the degree to which a firm mobilises available resources to achieve organisational goals in the face of an uncertain environment. Moreover, strategy facilitates an enterprise's ability to identify external opportunities and match those opportunities with internal capabilities so as to explore new markets and deliver innovative products [132,133]. As highlighted by Lawson and Samson, enterprises that are able to link their technological goals with overall business strategy are highly capable of bringing innovation [24]. Also, the focus on organisational learning as well as cooperation with other market actors is determined by the company's strategy. Another issue related to a firm's strategy refers to risk-taking. The ability and willingness to take risks have been recognised as an attribute of innovative business entities [134]. If risk-taking is in line with the firm's strategy, it enables people to experiment, try new ways of performing their tasks, learn from their mistakes, etc. In addition, the acceptance of risk implies the company's orientation towards inter-organisational cooperation. In turn, all these activities result in an increase in the firm's ability to innovate $[21,134]$.

Hypothesis 3 (H3). There is a positive relationship between the amount of internal expenditure on RED in industrial enterprises and their innovation capability. 
Hypothesis 4 (H4). The volume of employment in RED in manufacturing enterprises has a positive impact on their innovation capability.

Hypothesis 5 (H5). There is a positive relationship between the size of employment in the group of research and development workers in RED in manufacturing enterprises and their innovation capability.

Multiple researchers also highlight the role of leadership in supporting a firm's innovation capability $[24,42,133,135]$. A leader who focuses on innovation creates an appropriate environment in the company, cares about communication that allows knowledge and expertise sharing necessary to innovate and creates an organisational culture favourable to innovation, promoting creative thinking and acting $[47,136,137]$. Vincent et al. stress that managers can support a firm's ability to generate innovation by stimulating creativity, experimentation and openness to new ideas within the organisation. Moreover, it has been found that creativity is dependent on leaders' ability to create opportunities as well as to provide the needed resources [138].

Enterprise innovation capability, frequently based on R\&D efforts and expenditures, is characterised by the high risk that arises from the low predictability of the results of the conducted research and relatively long gestation period [139]. However, given that innovation plays a key role in strengthening a company's competitive advantage, the solution commonly adopted in the developed countries refers to public financial subsidies aimed at supporting firms' R\&D investments $[139,140]$. Despite the fact that some research provides mixed empirical evidence regarding the public support stimulant effect on firms' investments in R\&D [141-143], most researchers argue that public support dedicated to enhancing enterprises' innovation capability stimulates firms' $R \& D$ investments that result in generating innovation $[140,144-146]$. It has also been found that subsidised companies are characterised by the increase in the number of patent applications that are a widely used measure of an enterprise's innovation output [147]. Of particular interest is the fact that the positive impact of public financial support for the company's R\&D investments is shaped by factors determining the absorptive innovation capacity as human capital and undertaking cooperation with other market actors. Human capital significance refers to the fact that without well-educated and experienced employees, the process of generating innovation will not proceed effectively or will not occur at all, whereas undertaking inter-organisational cooperation allows access to external knowledge and funds and contributes to the improvement of the enterprise's innovation performance [139].

Hypothesis 6 (H6). Public support for manufacturing enterprises operating in Poland has a positive impact on their innovation capability.

\section{The Innovation Capability of Polish Manufacturing Companies}

The Global Innovation Index 2019 report developed by experts from Cornell University, INSEAD and the World Intellectual Property Organization shows that Poland is ranked at the 39th position in the ranking of innovativeness of economies out of 129 countries examined [147]. Most countries that are members of the European Union occupy higher positions in this ranking than Poland, only four economies (i.e., Bulgaria, Greece, Romania and Croatia) have a lower level of innovation than Poland. The countries of Central and Eastern Europe which Poland is most often compared with (i.e., the Czech Republic, Hungary and Slovakia) rank higher in this ranking: the Czech Republic-26th place, Hungary-33rd and Slovakia-37th. Therefore, it is worth looking at how the innovative capability of Polish enterprises has developed over the past few years. It is an essential variable that is used in the estimates of the level of innovation of individual countries. In the context of the development of the economy based on Industry 4.0, innovations introduced by industrial enterprises are particularly important, because there are breakthrough solutions that significantly change the existing, often traditional manufacturing processes, which, in turn, translates into saving resources and increasing operational efficiency. 
The analysis of the Central Statistical Office of Poland data on the innovation capability of manufacturing enterprises in the years 2009-2018 indicates a reasonably stable situation in this period as regards the share of innovation-active enterprises (i.e., those that introduced at least one product or process innovation in the period under review or implemented at least one innovation project that was interrupted or discontinued during the period under review or was not completed by the end of this period, meaning that it is still being continued) in the total number of manufacturing enterprises. In 2009, this share amounted to $18.1 \%$ (Table 1). A slight decrease occurred in the years 2010-2011 (by one and two percentage points, respectively), which was a consequence of the economic slowdown due to the global crisis in the years 2008-2009. In 2012, there was a slow increase in the share of innovation-active enterprises in the total number of industrial enterprises. In 2017, innovation-active enterprises constituted $18.5 \%$ of entities conducting activity in the industry and in the following year, as reported by the Central Statistical Office of Poland, as much as $24 \%$. However, it is worth noting here that such a significant increase in the share of innovation-active enterprises is mostly the result of a change in the research methodology that was made after the publication of the fourth, revised edition of the Oslo Manual 2018 [148]. The data of the Central Statistical Office of Poland also show that in manufacturing enterprises, in the entire analysed period, the share of entities that introduced process innovations (new or significantly improved processes) was slightly higher than product innovations (new or significantly improved products).

Table 1. The innovation capability of manufacturing companies in Poland in the years 2009-2018.

\begin{tabular}{|c|c|c|c|c|c|c|c|c|c|c|}
\hline Specification & 2009 & 2010 & 2011 & 2012 & 2013 & 2014 & 2015 & 2016 & 2017 & 2018 * \\
\hline $\begin{array}{l}\text { Innovation-active enterprises as } \\
\text { the share of total manufacturing } \\
\text { enterprises (introducing products } \\
\text { that are new or improved from } \\
\text { firm's point of view) }\end{array}$ & 12.7 & 12.1 & 11.2 & 11.2 & 11.0 & 11.7 & 11.8 & 12.4 & 12.0 & 16.8 \\
\hline $\begin{array}{l}\text { Innovation-active enterprises as } \\
\text { the share of total manufacturing } \\
\text { enterprises (introducing products } \\
\text { that are new or improved from } \\
\text { firm's point of view) }\end{array}$ & 7.0 & 6.8 & 6.1 & 5.6 & 5.7 & 6.2 & 6.5 & 6.3 & 6.0 & 7.5 \\
\hline
\end{tabular}

\section{Materials and Methodology}

In order to answer the question, "Which factors determine the innovation capability of manufacturing enterprises operating in Poland?" an econometric model for panel data was constructed. The source of data for the conducted analyses were the publications of the Central Statistical Office of Poland, which contain basic information on the activities of manufacturing enterprises and reports (publications) presenting the results of research on the innovation capability of enterprises. Such research is carried out in European Union countries as part of the international Community Innovation Survey (CIS) research program.

A total of 22 NACE (Nomenclature statistique des activités économiques dans la Communauté européenne) divisions representing the "Manufacturing" section were included in the analysis. The study did not include several NACE divisions for which it was not possible to obtain complete data relating to the innovation capability of enterprises. Data from 2011 to 2018 were used. 
The surveyed industry branches form a specific set of facilities in which firms' innovation capability is shaped by individual and common factors for all NACE divisions. For this reason, appropriate research methods should be applied to assess the impact of specific factors on firms' innovation capability belonging to different divisions. Panel models are suitable models for this type of research. Due to the lack of homogeneity of the studied NACE divisions, panel models provide excellent opportunities for analysing differences appearing in relation to individual objects and allow, when estimating parameters, using the estimators of the desired properties $[149,150]$.

The explanatory variable in the model was the participation of innovation-active enterprises in individual NACE divisions. On the contrary, the set of explanatory variables contained variables related to cooperation undertaken by enterprises operating in the individual departments of NACE. One of them is the participation of enterprises actively cooperating in the field of innovation activities with other enterprises or non-commercial institutions. The cooperation aimed at enhancing a firm's innovation capability should not be considered as ordering works with external contractors without active participation in their implementation. The second variable is the share of enterprises actively cooperating in the field of innovation capability under cluster initiatives. In addition, the variable concerning the internal expenditure of enterprises on $R \& D$ activities and the variable related to public aid, which refers to the support of enterprises by public authorities in the scope of their innovation capability, was included in the set of explanatory variables. The set of explanatory variables also includes the size of total employment in R\&D and a variable informing about employment in the group of researchers.

\section{The Results of Model Estimation}

The research hypotheses allowed model specification for panel data:

$$
\begin{aligned}
\text { Innov_Activ }_{j t}= & \alpha_{0}+\alpha_{1} \text { Cooper }_{j t}+\alpha_{2} \text { Cluster }_{j t} \\
& +\alpha_{3} \text { Expen_RD }_{j t}+\alpha_{4} \text { Empl_RD }_{j t}+\alpha_{5} \text { Resear_RD } D_{j t}+\alpha_{6} \text { Pub_Supp } \\
& +v_{j t} \\
& v_{j t}=e_{t}+u_{j}+\varepsilon_{j t}
\end{aligned}
$$

\begin{tabular}{|c|c|}
\hline Variable & Description of Variable \\
\hline Innov_Activ ${ }_{j t}$ & Innovation-active enterprises as the share of all enterprises, in $j$ NACE division, in the period $t$. \\
\hline Cooper $_{j t}$ & $\begin{array}{l}\text { Enterprises that participated in innovation-oriented inter-organisational cooperation as the } \\
\text { share of innovation-active enterprises, in } j \text { NACE division, in the period } t \text {. }\end{array}$ \\
\hline Cluster $_{j t}$ & $\begin{array}{l}\text { Enterprises that participated in innovation-oriented cluster cooperation as the share of } \\
\text { manufacturing enterprises participating in innovation-oriented cooperation, in } j \text { NACE } \\
\text { division, in the period } t \text {. }\end{array}$ \\
\hline Expen_RD $D_{j t}$ & Internal expenditures on R\&D activity, in $j$ NACE division, in the period $t$ (in current prices). \\
\hline Empl_RD $D_{j t}$ & Total employment in R\&D in $j$ NACE division, in the period $t$ (in full-time equivalents). \\
\hline Resear_RD $D_{j t}$ & Researchers employed in R\&D, in $j$ NACE division, in the period $t$ (in full-time equivalents). \\
\hline Pub_Supp $j t$ & $\begin{array}{l}\text { Enterprises which received public support for innovation, as the share of innovation-active } \\
\text { enterprises, in } j \text { NACE division, in the period } t \text {. }\end{array}$ \\
\hline$v_{j t}$ & $\begin{array}{l}\text { Random error in the object } j \text {, in the time period } t \text {, which consists of the following components: } \\
e_{t} \text {-impulses affecting all observations in the period } t ; u_{j} \text {-impulses affecting all observations } \\
\text { in the object } j ; \varepsilon_{j t} \text {-impulses affecting only observations in the object } j \text { in the period } t \text {. }\end{array}$ \\
\hline
\end{tabular}

The description of individual variables and the sources of data used are presented in Table 2.

Table 2. The variables used in empirical investigation. 
Due to the fact that the explained variable takes values from the interval $[0 ; 1]$ the logit transformation of the explanatory variable Innov_Activ ${ }_{j t}$ has been performed. The dependent variable was obtained in the form of logit $\left[\ln \left(I_{n n o v}{ }_{-} A c t i v_{j t} /\left(1-I n n o v \_A c t i v_{j t}\right)\right]\right.$ whose values belong to the range $(-\infty ; \infty)$. Thus, the possibility of obtaining the theoretical values of the Innov_Activ ${ }_{j t}$ index that exceed the allowed range $[0 ; 1]$ was eliminated.

\section{Results and Discussion}

The basic methods of estimating parameters in panel models are the estimator of fixed effects (FE) and the estimator of random effects (RE). Individual effects are a source of heterogeneity of the sample and refer to specific panel units [151,152]. The FE estimator assumes that individual effects are not random and it is possible to estimate them. In the case of the RE estimator, individual effects are treated as random and become a fragment of the random component. It is usually assumed that if the individual effect is uncorrelated with the explanatory variables, the estimator of the random effect (RE) should be used and in the case of correlations-the estimator of the fixed effect (FE). In the particular case, when all objects (panel units) are homogeneous and the deviations of the empirical values of the explained variable from the theoretical values are caused only by a random component, the estimator of the ordinary least squares (OLS) method can be used to estimate the parameters in the panel model.

The estimation of the panel data model designated with the Formula (1) was made with the use of the Gretl (GNU Regression Econometrics Time-Series Library version 9.1.14.) software (GNU General Public License, Free Software Foundation). There were no a priori assumptions made for the occurrence and significance of individual effects, as well as for the character of the individual effects (fixed or random). The choice of the estimation methods (pooled OLS, fixed effects, random effects) was made with the use of a decision procedure from the field of econometrics advocated in the literature [150]. The model was estimated with the use of a classical least squares method and diagnostic tests were performed and, as a result, the following values of the test statistics were obtained: the Wald test $(\mathrm{F}=34.5753, p$-value $<0.00001)$ the Breusch-Pagan test $(\mathrm{LM}=217.908, p$-value $<0.00001)$ and the Hausman test $(\mathrm{H}=43.2328, p$-value $<0.00001)$. On the basis of conducted diagnostic tests, it has been finally established, with the risk of error at the level of $0.05(\alpha=0.05)$, that the appropriate model for describing the studied dependence is the fixed effects model (FE). Therefore, the parameters of the fixed effects model were estimated. However, the phenomenon of heteroscedasticity occurred. Heteroscedasticity affects inappropriate estimations of standard errors for individual parameters and the revaluation of the determination coefficient, which may distort the conclusions regarding the significance of variables. Therefore, to estimate the parameters, ultimately, the weighted least-squares method was applied (WLS). The values of statistically significant parameters of the model described by the Formula (1) are presented in Table 3.

The model is correct in statistical terms. The general performance of the model is satisfactory (Adjusted $\mathrm{R}^{2}=0.746077$ ). Four potential explanatory variables were found to be significant. A variable that significantly and positively affects the innovation capability of manufacturing companies operating in Poland is their cooperation with other entities (i.e., other enterprises or non-commercial institutions, for example, universities or scientific and research centres). The obtained value of parameter $\alpha$ with the Cooper ${ }_{j t}$ variable informs that the increase in the share of enterprises that cooperate with other entities affects the overall innovation capability of manufacturing enterprises in Poland (here expressed as the logit of the Cooper $j$ variable) to a less than proportional degree. This is indicated by the value of parameter $\alpha$ for the Cooper $j t$ variable, which, in the estimated model, was 0.625330 . Such a result was to be expected because cooperation between enterprises is particularly conducive to the exchange of knowledge and experience. Partnership and cooperation functioning in this type of network of connections generate synergy effects that are necessary for the process of creating innovations. Our findings are aligned with the evidence found in the relevant literature. The positive outcomes of inter-organisational cooperation have been proven by several researchers $[10,43,104,153,154]$. Roper et al. claim that innovative companies mostly cooperate with 
their customers, suppliers, universities, as well as other public research centres [104]. Similarly, Farace and Mazzotta indicate that participating in inter-organisational networks increases a firm's innovation capability [43]. Also, the research findings provided recently by the Polish Agency for Enterprise Development (PARP) related to the monitoring of Polish enterprises innovativeness conducted in 2019, confirm that Polish enterprises, while searching for innovations, cooperate mainly with their customers (69\% of all Polish innovation-active firms from 2016 to 2019 ) and suppliers (46\% of all Polish innovation-active firms between 2016 and 2019) [155]. Also, companies' cooperation with research institutions has been proven in previous research to stimulate businesses' innovation capability. Such a relationship has been studied by Schubert and Robin who indicated that cooperating with public research increases product innovation [156]. On the basis of the obtained results regarding the Cooper ${ }_{j t}$ variable, it can be concluded that there are no grounds to reject the H1 hypothesis.

At the same time, the research shows that the Cluster ${ }_{j t}$ variable turned out to be statistically insignificant (at the significance level of 0.05 ), which means that the $\mathrm{H} 2$ hypothesis, according to which inter-organisational cooperation in the form of cluster initiatives should be a factor stimulating innovation capability of manufacturing enterprises in Poland, should be rejected. Taking into consideration that firms participating in clusters have been recognised as enhancing their ability to innovate [98-100], we suppose that our finding results from the fact that only $4 \%$ of Polish innovation-active companies declare to cooperate within clusters [155].

The results obtained indicate the importance of variables related to employing staff in R\&D activity in enterprises. The study shows that increased employment in R\&D has a positive impact on the innovation capability of enterprises only when it concerns researchers. This is indicated by the value of the $\alpha$ parameter next to the Resear $\_R D_{j t}$ variable $(\alpha=0.171018)$, which means that there are no grounds for rejecting the $\mathrm{H} 5$ hypothesis. Increasing total employment in $\mathrm{R} \& \mathrm{D}$ (the $E m p l \_R D_{j t}$ variable) is not a factor favouring the growth of enterprise innovation capability $(\alpha=-0.203150)$. Therefore, it can be concluded that R\&D employees (technicians and equivalent staff and other supporting staff), though certainly needed, do not significantly affect the growth of the innovation capability of enterprises. The obtained negative result of the parameter $\alpha$ for the $E m p l \_R D_{j t}$ variable may signify excessive employment in the group of non-research workers in the surveyed industrial enterprises. In this situation, it should be concluded that the $\mathrm{H} 4$ hypothesis, according to which the level of employment in R\&D activity in industrial enterprises has a positive impact on their innovation capability, should be rejected.

Research also shows that a statistically significant factor influencing the innovation capability of enterprises is the internal expenditure on $R \& D$ (for the variable Expen_R $D_{j t} \alpha=0.217961$ ). Therefore, there is no reason to reject the H3 hypothesis. Internal expenditures on R\&D include the expenditures incurred in a reporting year on R\&D activity in the reported entity, irrespective of the origin of such funds. They cover both current expenditures and investment outlays on fixed assets related to R\&D activity, but do not cover the depreciation of these assets. Intramural expenditures on R\&D activity are surveyed according to the costs category and according to sources of financing (i.e., sources of funds for this activity by entities conducting it). Our findings are compatible with the relevant literature. The positive effect of R\&D expenditures on a firm's innovation capability is proposed by several researchers [48,118-121].

The Pub_Sup jt variable turned out to be statistically insignificant (at the significance level of 0.05), which means that the H6 hypothesis, according to which the support of enterprises operating in Poland from public funds has a positive impact on their innovation capability, should be rejected. These findings seem to be aligned with the view of some researchers that public support for a firm's R\&D may crowd out firm-financed R\&D spending [155-159]. 
Table 3. The results of the estimation of the model describing the innovation capability of manufacturing enterprises in Poland.

\begin{tabular}{|c|c|c|c|c|c|c|c|c|c|c|}
\hline \multirow{3}{*}{ Independent Variables } & \multicolumn{10}{|c|}{ Dependent Variable In[Innov_Activ $\left.{ }_{j t} /\left(1-I n n o v \_A c t i v_{j t}\right)\right]$} \\
\hline & \multicolumn{5}{|c|}{ The Model before a posteriori Elimination } & \multicolumn{5}{|c|}{ The Model after a posteriori Elimination } \\
\hline & Coefficient & Standard Error & $t$-Ratio & $p$-Value & Significance ${ }^{(a)}$ & Coefficient & Standard Error & $t$-Ratio & $p$-Value & Significance ${ }^{(a)}$ \\
\hline const & -4.025410 & 0.265206 & -15.18 & $<0.00001$ & $* * *$ & -3.94663 & 0.227067 & -17.38 & $<0.00001$ & $* * *$ \\
\hline Cooper $_{j t}$ & 0.606359 & 0.0673053 & 9.009 & $<0.00001$ & $* * *$ & 0.625330 & 0.0598285 & 10.45 & $<0.00001$ & $* * *$ \\
\hline Cluster $_{j t}$ & -0.003636 & 0.021190 & -0.172 & 0.8637 & & & & & & \\
\hline Expen_RD $D_{j t}$ & 0.217961 & 0.0415166 & 5.250 & $<0.00001$ & $* * *$ & 0.221446 & 0.0404907 & 5.469 & $<0.00001$ & $* * *$ \\
\hline$E m p l \_R D_{j t}$ & -0.203150 & 0.0818217 & -2.483 & 0.0140 & $* *$ & -0.204349 & 0.0807056 & -2.532 & 0.0122 & $* *$ \\
\hline Resear_RD $D_{j t}$ & 0.171018 & 0.746521 & 2.291 & 0.232 & $* *$ & 0.164531 & 0.0712657 & 2.309 & 0.0222 & $* *$ \\
\hline Pub_Sup ${ }_{j t}$ & 0.0382506 & 0.0639111 & 0.599 & 0.5503 & & & & & & \\
\hline \multicolumn{2}{|l|}{ Observations } & \multicolumn{4}{|c|}{176} & \multicolumn{2}{|c|}{ Observations } & \multicolumn{3}{|c|}{176} \\
\hline \multicolumn{2}{|c|}{ Standard error of residuals } & \multicolumn{4}{|c|}{0.993230} & \multicolumn{2}{|c|}{ Standard error of residuals } & \multicolumn{3}{|c|}{0.992700} \\
\hline \multicolumn{2}{|c|}{$\mathrm{R}^{2}$} & \multicolumn{4}{|c|}{0.752016} & \multicolumn{2}{|c|}{$\mathrm{R}^{2}$} & \multicolumn{3}{|c|}{0.751881} \\
\hline \multicolumn{2}{|l|}{ Adjusted $\mathrm{R}^{2}$} & \multicolumn{4}{|c|}{0.743212} & \multicolumn{2}{|c|}{ Adjusted $\mathrm{R}^{2}$} & \multicolumn{3}{|c|}{0.746077} \\
\hline \multicolumn{2}{|c|}{$F(6 ; 169)=85.41595$} & \multicolumn{4}{|c|}{$p$-value for test $\mathrm{F}<0.00001$} & \multicolumn{2}{|c|}{$\mathrm{F}(4 ; 171)=129.5461$} & \multicolumn{3}{|c|}{$p$-value for test $\mathrm{F}<0.00001$} \\
\hline
\end{tabular}

(a) ** Statistically significant variable at the level of $5 \% ; * *$ Statistically significant variable at the level of $1 \%$. Source: The author's own calculations. 


\section{Conclusions}

The aim of the article was to identify the factors determining the innovation capability of manufacturing enterprises operating in Poland. The conducted analysis allowed us to verify the hypotheses that were formulated in the research process. The developed econometric panel data model showed that the factors driving the innovation capability of manufacturing enterprises operating in Poland are the following: inter-organisational cooperation, hiring employees in R\&D activities as well as firms' internal expenditures on R\&D.

Given the contemporary instability of the business environment, the acceleration of knowledge advancement leading to developing various categories of innovation, the innovation-oriented activity of a company is no longer dominated by operating independently. Success in this field requires collaboration with other entities, such as other companies, universities, research institutions. Cooperation is said to be a source of tangible business advantages that allow firms to expand the scope of R\&D projects and to tap into resources and expertise that would otherwise be deficient. Furthermore, employing researchers in companies' R\&D field and enterprises' internal expenditures on R\&D have proven to be significant factors in fostering the innovation capability of the analysed manufacturing enterprises operating in Poland. R\&D activity pursued by the company allows the creation of knowledge that fosters its ability to innovate, which translates into several outcomes regarding sustainability such as reducing carbon emissions, eliminating waste, the continual use of resources, etc. Thus, the internal expenditures on R\&D activity result not only in enhancing firms' innovation capability but also in strengthening their sustainability orientation.

Our results contribute both to the literature and practice in the field of enterprise innovation capability. Research presented in the literature on the determinants of innovation capability is most often of a qualitative nature. This article presents the author's concept of the determinants of the enterprises' innovation capability model using panel data. Based on the panel model, factors significantly affecting the innovation capability of Polish enterprises were identified. The results of the analysis can be a source of information both for enterprises as well as for authorities making decisions regarding the spending of public funds that are intended to support the innovation capability of Polish enterprises.

Our findings also have useful strategic implications for enterprises. As a firm's ability to innovate is a prerequisite for its competitiveness, managers need to make strategic decisions in terms of strengthening businesses' innovation capability in the long term. Our research results can help them make such a decision by showing that inter-organisational cooperation is, in fact, necessary to provide access to new knowledge, in particular, to allow absorption of new technologies, to gain access to global markets as well as human and material resources of other organisations. Furthermore, our results prove that investing in R\&D activity within a company brings about improvement in its innovation capability. This suggests that managers responsible for firms' performance in terms of innovation, must attach great importance to companies' internal expenditures on R\&D.

We are also aware that the current study is not free from limitations. First of all, due to the lack of availability of relevant data, the proposed model does not take into account some of the factors potentially influencing the innovation capability of enterprises described in the theoretical grounding. Some of them are unobservable features of the analysed industries, which, due to the lack of the possibility of operationalisation, increase the value of the residuals in the estimated model. Additionally, the model does not analyse the variables delayed in time. Thus, in the future, it would be possible to verify the dynamic model for panel data describing the determinants of innovativeness of enterprises in the analysed industries. The limitations of the conducted study simultaneously indicate future research directions. It would be interesting to enlarge the empirical analysis through the inclusion of a wider range of potential variables that may determine the innovation capability of industrial enterprises. Furthermore, extending the time of observation of the studied objects (by another dozen or so years) may reduce the impact of business cycles in the economy and individual industries. It is therefore worth verifying a similar model for panel data with a period extended by several years into the future. It could also be interesting to compare the results of our research on industrial enterprises with the 
results for enterprises operating in the services sector. In the context of research on determinants of innovation capability of enterprises, interesting conclusions can also be provided by international comparisons, for example, with other countries of Central and Eastern Europe or, even more broadly, with countries being members of the European Union.

Author Contributions: Conceptualisation, A.S., J.Ł.; methodology, J.Ł.; data retrieval, J.Ł.; formal analysis, A.S., J.Ł.; discussion, A.S.; writing—original draft preparation A.S., J.Ł.; writing—review and editing, A.S., J.Ł.; project administration, A.S., J.Ł.; visualisation, J.Ł.; funding acquisition, A.S., J.Ł. All authors have read and agreed to the published version of the manuscript.

Funding: This research was funded with a statutory research budget by the Faculty of Economic Sciences and Management, Nicolaus Copernicus University in Torun, Poland.

Conflicts of Interest: The authors declare no conflict of interest. The funders had no role in the design of the study; in the collection, analyses, or interpretation of data; in the writing of the manuscript, or in the decision to publish the results.

\section{References}

1. Trigo, A.; Vence, X. Scope and patterns of innovation cooperation in Spanish service enterprises. Res. Policy 2012, 41, 602-613. [CrossRef]

2. Trapczyński, P.; Puślecki, Ł.; Staszków, M. Determinants of Innovation Cooperation Performance: What Do We Know and What Should We Know? Sustainability 2018, 10, 4517. [CrossRef]

3. Jakimowicz, A.; Rzeczkowski, D. Do barriers to innovation impact changes in innovation activities of firms during business cycle? The effect of the Polish green island. Equilibrium 2019, 14, 631-676. [CrossRef]

4. Derevianko, O. Reputation stability vs. anti-crisis sustainability: Under what circumstances will innovations, media activities and CSR be in higher demand? Oecon. Copernic. 2019, 10, 511-536. [CrossRef]

5. Wrigley, C.; Bucolo, S.; Straker, K. Designing new business models: Blue sky thinking and testing. J. Bus. Strategy 2016, 37, 22-31. [CrossRef]

6. Roszko-Wójtowicz, E.; Grzelak, M.M.; Laskowska, I. The impact of research and development activity on the TFP level in manufacturing in Poland. Equilibrium 2019, 14, 711-737. [CrossRef]

7. Saadi, I.A.; Che Razak, R. Technological capability, Innovative Human Capital and Organizational Sustainability: A Proposed Framework. Int. J. Innov. Manag. Technol. 2019, 10, 219-228. [CrossRef]

8. Sriboonlue, P.; Ussahawanitchakit, P.; Raksong, S. Strategic innovation capability and firm sustainability: Evidence from auto parts business in Thailand. J. Bus. Retail. Manag. Res. 2016, 10, 11-29.

9. Dyllick, T.; Hockerts, K. Beyond the business case for corporate sustainability. Bus. Strategy Environ. 2002, 11, 130-141. [CrossRef]

10. Shan, W.; Zhang, C.; Wang, J. Internal Social Network, Absorptive Capacity and Innovation: Evidence from New Ventures in China. Sustainability 2018, 10, 1094. [CrossRef]

11. Albort-Morant, G.; Henseler, J.; Cepeda-Carrión, G.; Leal-Rodríguez, A.L. Potential and Realized Absorptive Capacity as Complementary Drivers of Green Product and Process Innovation Performance. Sustainability 2018, 10, 381. [CrossRef]

12. Scholten, V.E.; Blok, V. Foreword: Responsible innovation in private sector. J. Chain Netw. Sci. 2015, 15, 101-105. [CrossRef]

13. Lubberink, R.; Blok, V.; van Ophem, J.; Omta, O. Lessons from responsible innovations in the business context: A systematic literature review of responsible, social and sustainable innovation practices. Sustainability 2017, 9, 721. [CrossRef]

14. Ratten, V.; Ramirez-Pasillas, M.; Lundberg, H. Managing sustainable innovation. In Managing Sustainable Innovation; Ratten, V., Ramirez-Pasillas, M., Lundberg, H., Eds.; Routledge: New York, NY, USA, 2020; pp. 4-15, ISBN 0367210312.

15. Lewandowska, A.; Stopa, M. Do SME's innovation strategies influence their effectiveness of innovation? Some evidence from the case of Podkarpackie as peripheral region in Poland. Equilibrium 2019, 14, 521-536. [CrossRef]

16. Saxena, P.; Stavropoulos, P.; Kechagias, J.; Salonitis, K. Sustainability Assessment for Manufacturing Operations. Energies 2020, 13, 2730. [CrossRef]

17. Neely, A.; Adams, C.; Crowe, P. The performance prism in practice. Meas. Bus. Excell. 2001, 5, 6-13. [CrossRef] 
18. Olsson, A.; Wadell, C.; Odenrick, P.; Bergendahl, M.N. An action learning method for increased innovation capability in organisations. Action Learn. 2010, 7, 167-179. [CrossRef]

19. Saunila, M.; Ukko, J.A. Conceptual framework for the measurement of innovation capability and its effects. Balt. J. Manag. 2012, 7, 355-375. [CrossRef]

20. Lin, H.E.; McDonough, E.F.; Lin, S.J.; Lin, C.Y.Y. Managing the exploitation/exploration paradox: The role of a learning capability and innovation ambidexterity. J. Prod. Innovat. Manag. 2013, 30, 262-278. [CrossRef]

21. Raghuvanshi, J.; Ghosh, P.K.; Agrawal, R. Taxonomy of innovation capability framework with future directions. Int. J. Bus. Excell. 2019, 17, 265-289. [CrossRef]

22. Spitsin, V.; Mikhalchuk, A.; Chistyakova, N.; Spitsyna, L.; Pavlova, I. Development of innovative industries in Russia under unfavourable external environment. Equilibrium 2018, 13, 467-485. [CrossRef]

23. Narcizo, R.B.; Canen, A.G.; Tammela, L. A Conceptual Framework to Represent the Theoretical Domain of "Innovation Capability" in Organizations. J. Entrep. Manag. Innov. 2017, 13, 147-166. [CrossRef]

24. Lawson, B.; Samson, D. Developing innovation capability in organisations: A dynamic capabilities approach. Int. J. Innov. Manag. 2001, 5, 377-400. [CrossRef]

25. Skalická, M.; Zinecker, M.; Balcerzak, A.; Meluzín, T. Why Do Companies Go Public? Evidence from the Prague Stock Exchange. Entrep. Bus. Econ. Rev. 2019, 7, 181-199. [CrossRef]

26. Mohková, N.; Zinecker, M. Sovereign Debt and Corporate Capital Structure: The Evidence from Selected European Countries During the Global Financial and Economic Crisis. Bus. Theory Pract. 2017, 18, 14-24. [CrossRef]

27. Esterhuizen, D.; Schutte, C.; Du Toit, A. A knowledge management framework to grow innovation capability maturity. S. Afr. J. Inf. Manag. 2012, 14, 1-10. [CrossRef]

28. Wonglimpiyarat, J. Innovation index and the innovative capacity of nations. Futures 2010, 42, $247-253$. [CrossRef]

29. Rangone, A. A resource-based approach to strategy analysis in small-medium sized enterprises. Small Bus. Econ. 1999, 12, 233-248. [CrossRef]

30. Statystyczny, G.U. Działalność Innowacyjna Przedsiębiorstw w Latach 2012-2014; Główny Urząd Statystyczny: Warszawa, Poland, 2015.

31. Lendel, V.; Moravčíková, D.; Latka, M. Organizing Innovation Activities in company. Procedia Eng. 2017, 192, 615-620. [CrossRef]

32. Ključnikov, A.; Civelek, M.; Čech, P.; Kloudová, J. Entrepreneurial orientation of SMEs' executives in the comparative perspective for Czechia and Turkey. Oecon. Copernic. 2019, 10, 773-795. [CrossRef]

33. Mohannak, K. Innovation Networks and Capability Building in the Australian High-technology SMEs. Eur. J. Innov. Manag. 2007, 10, 236-251. [CrossRef]

34. Kastalli, I.V.; Neely, A. Collaborate to Innovate. How Business Ecosystems Unleash Business Value; University of Cambridge, Cambridge Service Alliance: Cambridge, UK, 2013.

35. Sudolska, A. Uwarunkowania Budowania Relacji Proinnowacyjnych Przez Przedsiębiorstwa w Polsce; Wydawnictwo Uniwersytetu Mikołaja Kopernika: Torun, Poland, 2011.

36. Tidd, J.; Bessant, J.; Pavitt, K. Managing Innovation. Integrating Technological, Market and Organizational Change; John Wiley\&Sons: Chichester, UK, 2006.

37. Saarenketo, S.; Kuivalainen, O.; Kylaheiko, K.; Puumalainen, K. Dynamic Knowledge-related Learning Processes in Internationalizing High-technology SMEs. Int. J. Prod. Econ. 2004, 89, 363-378. [CrossRef]

38. Zeng, S.X.; Xie, X.M.; Tam, C.M. Relationship between cooperation networks and innovation performance of SMEs. Technovation 2010, 30, 181-194. [CrossRef]

39. Glabiszewski, W.; Sudolska, A.; Górka, J.; Pańka, A. Financial Services Companies' Abilities to Collaborative Technology Absorption versus Their Innovativeness. In Contemporary Challenges in Cooperation and Coopetition in the Age of Industry 4.0; Springer: Cham, Switzerland, 2020; pp. 225-241, ISBN 9783030305482.

40. Polyanska, A.; Zapukhliak, I.; Diuk, O. Culture of organization in conditions of changes as an ability of efficient transformations: The case of gas transportation companies in Ukraine. Oecon. Copernic. 2009, 10, 561-580. [CrossRef]

41. Mattessich, P.W.; Murray-Close, M.; Monsey, B.R. Collaboration: What Makes It Work; Amherst H. Wilder Foundation: Saint Paul, MN, USA, 2001; ISBN 168336791X.

42. Slater, S.F.; Mohr, J.J.; Sengupta, S. Radical product innovation capability: Literature review, synthesis, and illustrative research propositions. J. Prod. Innovat. Manag. 2014, 31, 552-566. [CrossRef] 
43. Farace, S.; Mazzotta, F. The effect of human capital and networks on knowledge and innovations in SMEs. J. Innov. Manag. 2015, 1, 39-71. [CrossRef]

44. Ruffoni, E.P.; D’Andrea, F.A.M.; Kich Chaves, F.A.J.; Zawiślak, P.A.; Tello-Gamarra, J. R\&D investment and the arrangement of innovation capabilities in Brazilian manufacturing firms. J. Technol. Manag. Innov. 2018, 13, 74-83. [CrossRef]

45. Zygmunt, A. External linkages and intellectual assets as indicators of firms' innovation activities: Results from the Czech Republic and Poland. Oecon. Copernic. 2019, 10, 291-308. [CrossRef]

46. Mačerinskienè, I.; Survilaitè, S. Company's intellectual capital impact on market value of Baltic countries listed enterprises. Oecon. Copernic. 2019, 10, 309-339. [CrossRef]

47. Naranjo-Valencia, J.C.; Jimenez-Jimenez, D.; Sanz-Valle, R. Innovation or imitation? The role of organizational culture. Manage. Decis. 2011, 49, 55-72. [CrossRef]

48. Trott, P. Innovation Management and New Product Development; Prentice Hall: Upper Saddle River, NJ, USA, 2011; ISBN 9780273736561.

49. Lee, C.-Y. Competition favours the prepared firm: Firms' R\&D responses to competitive market pressure. Res. Pol. 2009, 38, 861-870. [CrossRef]

50. Dyer, J.H.; Singh, H. The relational view: Cooperative strategy and sources of interorganizational competitive advantage. Acad. Manag. Rev. 1998, 23, 660-679. [CrossRef]

51. Laursen, K.; Salter, A. Open for innovation: The role of openness in explaining innovation performance among U.K. manufacturing firms. Strateg. Manag. J. 2006, 27, 131-150. [CrossRef]

52. Cohen, W.M.; Levinthal, D.A. Absorptive Capacity: A New Perspective on Learning and Innovation. Admin. Sci. Quart. 1990, 35, 128-152. [CrossRef]

53. Colombo, M.G.; Grilli, L. Founders' Human Capital and the Growth of New Technology. Res. Policy 2005, 34, 795-816. [CrossRef]

54. Mariz-Pérez, R.M.; Teijeiro-Alvarez, M.M.; García-Alvarez, M.T. The relevance of human capital as a driver for innovation. Cuad. Econ. 2012, 35, 68-76. [CrossRef]

55. Glińska, A.; Sudolska, A.; Karwacki, A.; Górka, A. Innovations among people: How positive relationships at work can trigger innovation creation. EEM Ekon. Manag. 2017, 20, 84-100. [CrossRef]

56. Isaken, S.G.; Lauer, K.J.; Ekval, G.; Britz, A. Perceptions of the Best and Worst Climates for Creativity: Preliminary Validation Evidence for Situational Outlook Questionnaire. Creat. Res. J. 2001, 13, 171-184. [CrossRef]

57. Loewe, P.; Dominiquini, J. Overcoming the barriers to effective innovation. Strategy Leadersh. 2006, 34, $24-31$. [CrossRef]

58. Isaken, S.G.; Ekval, G. Managing for Innovation: The Two Faces of Tension in Creative Climates. Creat. Innov. Manag. 2010, 19, 73-88. [CrossRef]

59. Barney, J.B. Firm Resources and Sustained Competitive Advantage. J. Manag. 1991, 17, 99-120. [CrossRef]

60. Peteraf, M.A. The cornerstones of competitive advantage: A resource-based view. Strateg. Manag. J. 1993, 14, 179-191. [CrossRef]

61. Świadek, A. Sales range and innovative activity in the manufacturing system of Poland. Equilibrium 2018, 13, 725-740. [CrossRef]

62. Świadek, A.; Dzikowski, P.; Tomaszewski, M.; Gorączkowska, J. Sectoral patterns of innovation cooperation in Polish industry. Equilibrium 2019, 14, 183-200. [CrossRef]

63. Miotti, L.; Sachwald, F. Co-operative R\&D: Why and with whom? An integrated framework of analysis. Res. Policy 2003, 1607, 1-19. [CrossRef]

64. Williamson, O.E. Comparative Economic Organization: The Analysis of Discrete Structural Alternatives. Admin. Sci. Quart. 1991, 36, 269-296. [CrossRef]

65. Zajac, E.J.; Olsen, C.P. From transaction cost to transactional value analysis: Implications for the study of interorganizational strategies. J. Manag. Stud. 1993, 30, 131-145. [CrossRef]

66. Mowery, D.C.; Oxley, J.E.; Silverman, B.S. Strategic alliances and interfirm knowledge transfer. Strateg. Manag. J. 1996, 17, 77-91. [CrossRef]

67. Pfeffer, J.; Salancik, G. The External Control of Organizations: A Resource Dependence Perspective; Harper\&Row: New York, NY, USA, 1978.

68. Gulati, R.; Nohira, N.; Zaheer, A. Strategic networks. Strateg. Manag. J. 2000, 21, 203-215. [CrossRef]

69. Gulati, R. Managing Network Resources. Alliances, Affiliations and Other Relational Assets; Oxford University Press: New York, NY, USA, 2007; ISBN 9780199299355. 
70. Gkypali, A.; Filiou, D.; Tsekouras, K. R\&D Collaborations: Is Diversity Enhancing Innovation Performance? Technol. Forecast. Soc. Chang. 2017, 118, 143-152. [CrossRef]

71. Teece, D.J.; Pisano, G.; Shuen, A. Dynamic capabilities and strategic management. Strateg. Manag. J. 1997, 18, 509-533. [CrossRef]

72. Colombo, M.G.; Laursen, K.; Magnusson, M.; Rossi-Lamastra, C. Organizing inter- and intra-firm networks: What is the impact on innovation performance? Ind. Innov. 2011, 18, 531-538. [CrossRef]

73. Lavie, D. The Competitive Advantage of Interconnected Firms: An Extension of the Resource-Based View. Acad. Manag. Rev. 2006, 31, 638-658. [CrossRef]

74. Pouwels, I.; Koster, F. Inter-organizational cooperation and organizational innovativeness A comparative study. Int. J. Innov. Sci. 2017, 9, 184-204. [CrossRef]

75. Piga, C.; Vivarelli, M. Sample selection in estimating the determinants of cooperative R\&D. Appl. Econ. Lett. 2003, 10, 243-246. [CrossRef]

76. Belderbos, R.; Duysters, G.; Sabidussi, A. RED Collaboration and Innovative Performance In Innovation and Growth: From RED Strategies of Innovating Firms to Economy-Wide Technological Change; Andersson, M., Karlsson, C., Lööf, H., Eds.; Oxford University Press: Oxford, UK, 2012.

77. Dyer, J.H. Effective Interfirm Cooperation: How Firms Minimize Transaction Costs and Maximize Transaction Value. Strateg. Manag. J. 1997, 18, 535-556. [CrossRef]

78. Goold, M.; Campbell, A. Desperately Seeking Synergy. Harvard Bus. Rev. 1998, 76, 130-143.

79. Cannon, J.P.; Homburg, C. Buyer-Supplier Relationships and Customer Firms Costs. J. Mark. 2001, 65, $29-43$. [CrossRef]

80. Hennart, J.-F. Transaction Cost Theory and International Business. J. Retail. 2010, 86, 257-269. [CrossRef]

81. Teece, D.J. Economies of Scope and the Scope of the Enterprise. J. Econ. Behav. Organ. 1980, 1, $223-247$. [CrossRef]

82. Panzar, J.C.; Willing, R.D. Economies of Scope. Am. Econ. Rev. 1981, 71, 268-272.

83. Ahuja, G. The duality of collaboration: Inducements and opportunities in the formation of interfirm linkages. Strateg. Manag. J. 2000, 21, 317-343. [CrossRef]

84. Tsai, K. Collaborative networks and product innovation performance: Toward a contingency perspective. Res. Policy 2009, 38, 765-778. [CrossRef]

85. Cohen, W.M.; Levinthal, D.A. Innovation and Learning: The Two Faces of R\&D. Econ. J. 1989, 99, $569-596$. [CrossRef]

86. Zahra, S.A.; George, G. Absorptive capacity: A review, reconceptualization, and extension. Acad. Manag. Rev. 2002, 27, 185-203. [CrossRef]

87. Waarts, E.; Van Everdingen, Y.M.; Van Hillegersberg, J. The Dynamics of Factors Affecting the Adoption of Innovation. J. Prod. Innovat. Manag. 2002, 19, 412-423. [CrossRef]

88. Salazar, A.; Gonzalez, J.M.H.; Duysters, G.; Sabidussi, A.; Allen, M. The value for innovation of inter-firm networks and forming alliances: A meta-analytic model of indirect effects. Comput. Hum. Behav. 2016, 64, 285-298. [CrossRef]

89. Calantone, R.J.; Cavusgil, S.T.; Zhao, Y. Learning orientation, firm innovation capability, and firm performance. Ind. Mark. Manag. 2002, 31, 515-524. [CrossRef]

90. Lundvall, B.A. National Systems of Innovation: Towards a Theory of Innovation and Interactive Learning; Anthem Press: London, UK, 2010; ISBN 9781843318903.

91. Sudolska, A.; Lis, A. Building a model of successful collaborative learning for company innovativeness. J. Entrep. Manag. Innov. 2014, 10, 109-137. [CrossRef]

92. García-Sánchez, E.; García-Morales, V.J.; Martín-Rojas, R. Influence of Technological Assets on Organizational Performance through Absorptive Capacity, Organizational Innovation and Internal Labour Flexibility. Sustainability 2018, 10, 770. [CrossRef]

93. Delmas, M.; Hoffmann, V.H.; Kuss, M. Under the tip of the iceberg: Absorptive capacity, environmental strategy, and competitive advantage. Bus. Soc. 2011, 50, 116-154. [CrossRef]

94. Sun, P.Y.T.; Anderson, M.H. An Examination of the Relationship Between Absorptive Capacity and Organizational Learning, and a Proposed Integration. Int. J. Manag. Rev. 2010, 12, 130-150. [CrossRef]

95. Hue, T.T. The determinants of innovation in Vietnamese manufacturing firms: An empirical analysis using a technology-organization-environment framework. Eurasian Bus. Rev. 2019, 9, 247-267. [CrossRef] 
96. Subramaniam, M.; Youndt, M.A. The influence of intellectual capital on the types of innovative capabilities. Acad. Manag. J. 2005, 48, 450-463. [CrossRef]

97. March, J.M. Exploration and Exploitation in Organizational Learning. Organ. Sci. 1991, 2, 71-87. [CrossRef]

98. Tsai, W. Knowledge transfer in intraorganizational networks: Effects of network position and absorptive capacity on business unit innovation and performance. Acad. Manag. J. 2001, 44, 996-1004. [CrossRef]

99. Ethiraj, S.K.; Kale, P.; Krishnan, M.S.; Singh, J.V. Where do capabilities come from and how do they matter? A study in the software services industry. Strateg. Manag. J. 2005, 26, 25-45. [CrossRef]

100. Fosfuri, A.; Tribó, J.A. Exploring the antecedents of potential absorptive capacity and its impact on innovation performance. Omega 2008, 36, 173-187. [CrossRef]

101. Ritter, T.; Gemunden, H.G. Network competence: Its impact on innovation success and its antecedents. J. Bus. Res. 2003, 56, 745-755. [CrossRef]

102. Hanna, V.; Walsh, K. Small Firm Networks: A Successful Approach to Innovation? RD Manag. 2002, 32, 201-207. [CrossRef]

103. Huxham, C.; Vangen, S. Managing to Collaborate; Routledge: New York, NY, USA, 2006; ISBN 0415339200.

104. Roper, S.; Du, J.; Love, J.H. Modelling the Innovation Value Chain. Res. Policy 2008, 37, 961-977. [CrossRef]

105. Forsman, H. Innovation Capacity and Innovation Development in Small Enterprises. A Comparison between the Manufacturing and Service Sectors. Res. Policy 2011, 40, 739-750. [CrossRef]

106. Stuart, T.E. Interorganizational Alliances and the Performance of Firms: A Study A Study of Growth and Innovation Rate in a High Technology Industry. Strateg. Manag. J. 2000, 21, 791-811. [CrossRef]

107. Child, J.; Faulkner, D.; Tallman, S.B. Cooperative Strategy: Managing Alliances, Networks and Joint Ventures; Oxford University Press: New York, NY, USA, 2005; ISBN 0199266255.

108. Comi, A.; Eppler, M.J. Building Strategic Alliances in New and Small Ventures: A Review of Literature and Integrative Framework. In Strategic Alliances for SME Development; Das, T.K., Ed.; Information Age Publishing: Charlotte, NC, USA, 2015; pp. 61-94, ISBN 9781681231792.

109. Mazur, V.V.; Barmuta, K.A.; Demin, S.S.; Tikhomirov, E.A.; Bykovskiy, M.A. Innovation Clusters: Advantages and Disadvantages. Int. J. Econ. Fin. Issues 2016, 6, 270-274.

110. Porter, M.E. Clusters and the New Economics of Competition. Harvard Bus. Rev. 1998, 76, 77-90.

111. Razminiene, K. Circular economy in clusters' performance evaluation. Equilibrium 2019, 14, 537-559. [CrossRef]

112. Broströn, A.; Lööf, H. What do You Know about Firms Research Collaboration with Universities? New Quantitative and Qualitative Evidence; Working Paper Series in Economics and Institutions of Innovation 74; The Royal Institute of Technology Centre of Excellence for Science and Innovation Studies: Stockholm, Sweden, 2006.

113. Myoken, Y. The role of geographical proximity in university and industry collaboration: Case study of Japanese companies in the UK. Int. J. Technol. Tran. Com. 2013, 12, 43-61. [CrossRef]

114. Künzel, M.; Meier zu Köcker, G.; Köhler, T. Clusters and Innovations Cluster Initiatives as Drivers of Innovations; ClusterAgentur Baden-Württemberg: Stuttgart, Germany, 2016.

115. Preissl, B.; Solimene, L. The Dynamics of Clusters and Innovation: Beyond Systems and Networks; Springer: Berlin/Heidelberg, Germany, 2003; ISBN 3790800775.

116. Breschi, S.; Malerba, F. Clusters, Networks, and Innovation: Research Results and New Directions. In Clusters, Networks, and Innovation; Breschi, S., Malerba, F., Eds.; Oxford University Press: New York, NY, USA, 2005; pp. 1-28, ISBN 9780199275564.

117. Hoffmann, V.E.; Molina-Morales, F.X.; Martínez-Fernández, M.T. Evaluation of competitiveness in ceramic industrial districts in Brazil. Eur. Bus. Rev. 2011, 23, 87-105. [CrossRef]

118. Baumann, J.; Kritikos, A.S. The Link between R\&D, Innovation and Productivity. Are micro firms different. Res. Policy 2016, 45, 1263-1274. [CrossRef]

119. Krishnaswamy, K.N.; Mathirajan, M.; Subrahmanya, M.H.B. Technological innovations and its influence on the growth of auto component SMEs of Bangalore: A case study approach. Technol. Soc. 2014, 38, 18-23. [CrossRef]

120. Chamsuk, W.; Fongsuwan, W.; Takala, J. The effects of R\&D and innovation capabilities on the Thai automotive industry part's competitive advantage: A SEM approach. Manag. Prod. Eng. Rev. 2017, 8, 101-112. [CrossRef]

121. Zhang, J.; Islam, M.S. The Heterogeneous Impacts of R\&D on Innovation in Services Sector: A Firm-Level Study of Developing ASEAN. Sustainability 2020, 12, 1643. [CrossRef] 
122. Savrul, M.; Incekara, A. The Effect of R\&D Intensity on Innovation Performance: A Country Level Evaluation. Procedia Soc. Behav. Sci. 2015, 210, 388-396. [CrossRef]

123. Guo, B.; Wang, J.; Wei, S.X. R\&D spending, strategic position and firm performance. Front. Bus. Res. China 2018, 12, 14. [CrossRef]

124. Ortega-Argilés, R.; Piva, M.; Vivarelli, M. The productivity impact of R\&D investment: Are high-tech sectors still ahead? Econ. Innov. New Technol. 2015, 24, 204-222. [CrossRef]

125. Malerba, F.; Mani, S. Sectoral Systems of Innovation and Production in Developing Countries: Actors, Structure and Evolution; Edward Elgar Publishing: Northampton, MA, USA, 2009; ISBN 9781848446564.

126. Chittoor, R.; Sarkar, M.; Ray, S.; Aulakh, P.S. Third-World Copycats to Emerging Multinationals: Institutional Changes and Organizational Transformation in the Indian Pharmaceutical Industry. Organ. Sci. 2008, 20, 187-205. [CrossRef]

127. Reichert, F.M.; Zawiślak, P.A. Technological capability and firm performance. J. Technol. Manag. Innov. 2014, 9, 20-35. [CrossRef]

128. Ballot, G.; Fakhfakh, F.; Taymal, E. Firm's Human Capital, R\&D and Performance: A Study of French and Swedish Firms. Labour Econ. 2001, 8, 443-462.

129. D'Amore, R.; Iorio, R.; Lubrano Lavedera, G. Exploring the Relationship Between Human Capital and Innovation at the Firm Level: A study on a Sample of European Firms; CELPE Discussion Papers 144; CELPE—Centre of Labour Economics and Economic Policy; University of Salerno: Salerno, Italy, 2017; pp. 1-31.

130. Börjesson, S.; Elmquist, M. Developing innovation capabilities: A longitudinal study of a project at Volvo Cars. Creat. Innov. Manag. 2011, 20, 171-184. [CrossRef]

131. Vicente, M.; Abrantes, J.L.; Teixeira, M.S. Measuring innovation capability in exporting firms: The INNOVSCALE. Int. Market. Rev. 2015, 32, 29-51. [CrossRef]

132. Wang, C.L.; Ahmed, P.K. The development and validation of the organisational innovativeness construct using confirmatory factor analysis. Eur. J. Innov. Manag. 2004, 7, 303-313. [CrossRef]

133. Iddris, F. Innovation capability: A systematic review and research agenda. Interdiscip. J. Inf. Knowl. Manag. 2016, 11, 235-260. [CrossRef]

134. Camps, S.; Marques, P. Exploring how social capital facilitates innovation: The role of innovation enablers. Technol. Forecast. Soc. 2014, 88, 325-348. [CrossRef]

135. Saunila, M.; Pekkola, S.; Ukko, J. The relationship between innovation capability and performance: The moderating effect of measurement. Int. J. Prod. Perf. Manag. 2014, 63, 234-249. [CrossRef]

136. Şen, A.; Eren, E. Leadership for the Twenty-First Century. Proced. Soc. Behav. Sci. 2012, 41, 1-14. [CrossRef]

137. Wolf, P.; Kaudela-Baum, S.; Meissner, J.O. Exploring innovating cultures in small and medium-sized enterprises: Findings from Central Switzerland. Int. Small Bus. J. 2012, 30, 242-274. [CrossRef]

138. Prajogo, D.I.; Ahmed, P.K. Relationships between innovation stimulus, innovation capacity, and innovation performance. RD Manag. 2006, 36, 499-515. [CrossRef]

139. Kijek, T.; Matras-Bolibok, A.; Rycaj, E. Do Public R\&D Expenditures Foster Business R\&D Investments? Int. J. Synerg. Res. 2020, 5, 147-154. [CrossRef]

140. Canter, U.; Kösters, S. Public R\&D Support for Newly Founded Firms-Effects on Patent Activity and Employment Growth. J. Innov. Econ. Manag. 2015, 16, 7-37.

141. David, P.A.; Hall, B.H.; Toole, A.A. Is Public R\&D a Complement or Substitute for Private R\&D? A Review of the Econometric Evidence. Res. Policy 2000, 29, 497-529. [CrossRef]

142. Alonso-Borrego, C.; Forcadell, F.J.; Galán-Zazo, J.I.; Zúñiga-Vicente, J.A. Assessing the Effect of Public Subsidies on Firm RED Investment: A Survey; Working Paper 12-15 Economic Series; Universidad Carlos III de Madrid: Madrid, Spain, 2012; pp. 1-42.

143. Catozella, A.; Vivarelli, M. The Possible Adverse Impact of Innovation Subsidies: Some Evidence from Italy. Int. Entrepren. Manag. J. 2016, 12, 351-368. [CrossRef]

144. Czarnitzki, D.; Bento, C.L. Evaluation of Public R\&D Policies: A Cross-Country Comparison. World Rev. Sci. Technol. Sustain. Dev. 2012, 9, 2-4. [CrossRef]

145. Bérubé, C.; Mohnen, P. Are Firms that Receive R\&D Subsidies More Innovative? Can. J. Econ. 2009, 42, 206-225. [CrossRef]

146. Czarnitzki, D.; Licht, G. Additionality of public R\&D grants in a transition economy-The case of Eastern Germany. Econ. Transit. 2006, 14, 101-131. [CrossRef] 
147. The Global Innovation Index 2019(WIPO). Creating Healthy Lives-The Future of Medical Innovation; Dutta, S., Lanvin, B., Wunsch-Vincent, S., Eds.; Cornell University: Ithaca, NY, USA, 2019; ISBN 9791095870142.

148. Oslo Manual 2018(OECD). Guidelines for Collecting, Reporting and Using Data on Innovation; OECD Publishing: Paris, France, 2018; ISBN 9789264304604.

149. Hsiao, C. Analysis of Panel Data; Cambridge University Press: Cambridge, UK, 2003; ISBN 0521818559.

150. Baltagi, B.H. Econometric Analysis of Panel Data; John Wiley\&Sons: Chichester, UK, 2013; ISBN 978-1-118-67232-7.

151. Maddala, G.S. Introduction to Econometrics; Macmillan Publishing Company: New York, NY, USA, 1992; ISBN 0023745452.

152. Banaszewska, M. The determinants of local public investments in Poland. Equilibrium 2018, 13, $105-121$. [CrossRef]

153. Robertson, P.L.; Jacobson, D.; Langloois, R.N. Innovation Processes and Industrial District. In Handbook of Industrial Districts; Becattini, G., Bellandi, M., De Propris, L., Eds.; Edward Elgar: Cheltenham, UK, 2009; pp. 269-280, ISBN 9781847202673.

154. De Jong, J.P.J.; Vermeulen, P.A.M. Determinants of Product Innovation in Small Firms: A Comparison across Industries. Int. Small Bus. J. 2004, 24, 587-609. [CrossRef]

155. Monitoring Innowacyjności Polskich Przedsiębiorstw. Wyniki II Edycji Badania 2019; Polska Agencja Rozwoju Przedsiębiorczości: Warszawa, Poland, 2019. Available online: https:/www.parp.gov.pl/component/ publications/publication/monitoring-innowacyjnosci-polskich-przedsiebiorstw-wyniki-ii-edycji-badania2019 (accessed on 31 August 2020).

156. Schubert, T.; Robin, S. Cooperation with public research institutions and success in innovation: Evidence from France and Germany. Res. Policy 2013, 42, 149-166. [CrossRef]

157. Wallsten, S.J. The Effects of Government-Industry R\&D Programs on Private R\&D: The Case of the Small Business Innovation Program. RAD J. Econ. 2000, 31, 82-100. [CrossRef]

158. Garcia, A.; Mohnen, P. Impact of Government Support on RED and Innovation; MERIT Working Papers 2010-034; United Nations University-Maastricht Economic and Social Research Institute on Innovation and Technology (MERIT): Maastricht, The Netherlands, 2010; ISSN 1871-9872.

159. Catozzella, A.; Vivarelli, M. Beyond Additionality: Are Innovation Subsidies Counterproductive? IZA Discuss. Pap. 2011, 5746, 4-25.

(C) 2020 by the authors. Licensee MDPI, Basel, Switzerland. This article is an open access article distributed under the terms and conditions of the Creative Commons Attribution (CC BY) license (http://creativecommons.org/licenses/by/4.0/). 